J. Perinat. Med. $11(1983) 155$

\title{
Blood glucose concentration in heavy-for-date infants
}

\author{
A. H. Dawodu, G. Russell, R. Dinwiddie, H. Thom, H. W. Sutherland, J. M. Stowers
}

Aberdeen Maternity Hospital and Departments of Child Health and Obstetrics, University of Aberdeen

It has long been recognized that diabetes mellitus and gestational diabetes during pregnancy are associated with the birth of unusually heavy infants $[5,14,19]$ and that the birth of a heavy infant may indicate the presence of otherwise unsuspected maternal diabetes $[12,13]$. It has therefore been recommended that women bearing infants weighing $4.5 \mathrm{~kg}$ or more be classified as potential diabetics [25]. The infants themselves may also have problems and abnormally rapid glucose disappearance rates have been noted in about one-fifth of infants weighing $4.5 \mathrm{~kg}$ or more $[6,17]$.

As an alternative to the use of an absolute birthweight criterion in the identification of the potentially diabetic mother we have investigated the use of birth-weight related to gestation $[8,21]$, defining a "heavy-for dates" (HFD) those infants with birth-weights above the 95 th centile for gestational age after adjustments for the birth rank and sex of the infant and the height, mid pregnancy weight and social class of the mother $[9,22]$. In a pilot study [18] we investigated glucose tolerance in twelve HFD infants and found that one-third of the infants had hyperinsulinism with enhanced glucose tolerance of a type usually associated with maternal diabetes. We have also shown that seven per cent of pregnant women who had previously given birth to a HFD baby had intravenous glucose tolerance test results in the diabetic range [21]. Although we have not shown that these biochemical abnormalities are associated with any clinical

\section{Curriculum vitae}

ADEKUNLE DAWODU was born in 1942 and studied medicine at the University of Ibadan Medical School in Nigeria, qualifying in 1968. After clinical work in pediatrics in Nigeria and Britain, he was elected MRCP (UK) in 1974. While Registrar in Pediatrics in Aberdeen Maternity Hospital he developed his interest in neonatal glucose homeostasis as a member of the Aberdeen Diabetic Pregnancy Study Group. He is presently a Lecturer (with special interest in Neonatology) in the Department of Pediatrics of Ibadan University. His current interests include nutrition and later development of Nigerian low birthweight infants.

abnormality, it can reasonably be deduced that the HFD infant is at increased risk of developing hypoglycemia, and it has been recommended that HFD infants should be included in screening programmes for neonatal hypoglycemia $[3,17,20]$.

The present study was designed to establish the incidence of hypoglycemia in HFD infants.

\section{Patients and methods}

Twenty-five HFD term infants (thirteen females and twelve males, mean birthweight $4480 \mathrm{~g} \pm$ SD 270 , mean gestational age $40.2 \mathrm{w} \pm \mathrm{SD} 0.94$ ) were studied during the first 24 hours of life. Excluded from the study were infants whose mothers were 
known to have diabetes or gestational diabetes, pre-eclamptic toxemia or Rhesus iso-immunization. Parental consent was obtained in all cases.

Maternal venous blood and umbilical venous blood (from the placental side) were taken immediately after delivery. Capillary blood was then obtained from a warmed heel from each baby at the age of one hour and before feeds at the ages of $4,8,16$, and 24 hours; on each of these specimens plasma glucose was estimated using the BECKMAN Glucose Analyser [13], and plasma insulin was estimated by radioimmunoassay using the LEPETIT Insulin Kit. (LEPETIT PhaRMACEUTICALS LTD, Nicholson House, High Street, Maidenhead, Berks).

The initial clinical examination of each baby included gestational age assessment [8] as a check on the gestation calculated from the mother's age. Meaurements of crown-heel and crown-rump length, and head circumference were made. Measurements of left triceps, left subscapular, left thigh and abdominal (mid way between the umbilicus and the left iliac crest) skin-fold thickness were made by the same examiner using the VEREL and KESTERVEN [24] calipers as described by FARR [7].

All infants were fed according to the established feeding regimen for normal term babies on the unit, except that feeds were offered to the infants at precise ages, rather than" "on demand" or at routine ward feeding-times. Feeds (COW \& GATE LTD, Trowbridge, Wiltshire, BA14 8HZ, England) providing $235 \mathrm{~kJ}$ per $100 \mathrm{ml}$ were started at the age of four hours and continued at four-hourly intervals thereafter. The 'volume of feed taken was determined by the infant; no attempt was made to force the infant to consume a particular volume of feed.

Treatment was started if any of the babies was found to be hypoglycemic (plasma glucose $\leqslant 2 \mathrm{mmol} / \mathrm{l}$ ); this normally took the form of supplementation of oral feeds with additional carbohydrate in the form of Caloreen (ROUSSEL NUTRITIONAL Division, Wembley Park, HA9 ONF, England). One infant with symptomatic hypoglycemia received intravenous glucose.

An intravenous glucose tolerance test [21] was performed post-partum on nine of the mothers.

\section{Results}

\subsection{Glucose and insulin concentrations}

Tab. I summarizes the results of the plasma glucose and insulin measurements in the 25 patients studied. The values for one baby (see para 2.5) at zero and 1 hour were not included in the statistical evaluation of the results since the cord glucose level and the cord and one-hour insulin levels were clearly outliers.

\subsection{Incidence of hypoglycemia}

CORNBLATH and SCHWARTZ [4] defined neonatal hypoglycemia as two glucose values less than

Tab. I. Glucose and insulin concentrations. Conversion: $1 \mathrm{mmol} / 1 \mathrm{plasma}$ glucose $=18 \mathrm{mg} / 100 \mathrm{ml}$.

\begin{tabular}{llllllrrr}
\hline & \multicolumn{1}{l}{ Plasma glucose } & \multicolumn{5}{c}{ Plasma insulin } \\
\hline Sample & $\mathrm{n}$ & mean & SD & range & $\mathrm{n}$ & mean & SD & range \\
\hline Maternal & 22 & 8.0 & 4.0 & $2.2-17.0$ & & & \\
Cord & 21 & 4.9 & 3.2 & $2.1-16.1$ & 20 & 32.5 & 81.6 & $1-374$ \\
& $20^{*}$ & 4.4 & 2.0 & $2.1-9.9$ & $19 * *$ & 14.5 & 14.2 & $1-53$ \\
1-hour & 24 & 2.3 & 1.0 & $0.8-5.6$ & 22 & 11.3 & 17.6. & $0-86$ \\
& & & & & $21 * * *$ & 7.7 & 5.8 & $0-18$ \\
4-hour & 25 & 3.0 & 0.8 & $1.5-4.8$ & 21 & 6.3 & 20.0 & $0-18$ \\
8-hour & 25 & 3.1 & 0.7 & $1.6-4.3$ & 23 & 11.4 & 12.8 & $0-59$ \\
16-hour & 25 & 3.22 & 0.17 & $2.3-5.0$ & 20 & 7.4 & 6.7 & $0-25$ \\
24-hour & 25 & 3.1 & 0.6 & $1.0-4.1$ & 15 & 7.1 & 8.0 & $0-27$ \\
\hline
\end{tabular}

* Excluding one result of $16.1 \mathrm{mmol} / 1$

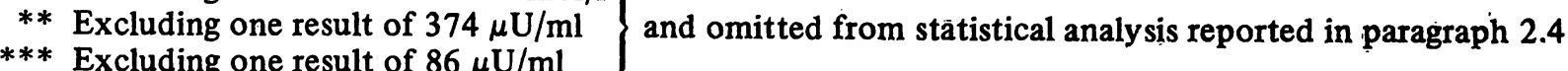


$30 \mathrm{mg}$ per $\mathrm{dl}$ in the term infant and two values less than $20 \mathrm{mg}$ per $\mathrm{dl}$ in low birth weight infants. PAGLIARA et al. [16] suggested that glucose concentrations below $40 \mathrm{mg}$ per dl constituted hypoglycemia while LILIEN et al. [10] used $35 \mathrm{mg}$ per dl for infants of normal birth weight. Each author has used conveniently rounded numbers which, in SI units, range from 1.11 to $2.22 \mathrm{mmol} / 1$. We have adopted the appropriate rounded SI units of $2 \mathrm{mmol} / 1$ to define mild hypoglycemia and $1.5 \mathrm{mmol} / 1$ to define definite hypolgycemia in our infants, all of whom had high birth weights.

Eleven of the 25 infants studied had a plasma glucose concentration $\leqslant 2 \mathrm{mmol} / 1$ at least once within the first 24 hours of life; of these, seven (28 per cent) had plasma glucose concentrations $\leqslant 1.5 \mathrm{mmol} / 1$. In all but one instance, the hypoglycemia occurred within the first eight hours of life, and at the age of one hour, seven infants were hypoglycemic, four with plasma glucose concentrations $\leqslant 1.5 \mathrm{mmol} / 1$.

\subsection{Symptoms of hypoglycemia}

In only three cases was the hypoglycemia symptomatic: One infant developed vomiting and cyanosis with a plasma glucose concentration $1.5 \mathrm{mmol} / 1$ at the age of 4 hours, another became jittery and irritable with a plasma glucose concentration of $1.6 \mathrm{mmol} / 1$ at the age of 8 hours and the third developed vomiting with a plasma glucose concentration of $1.0 \mathrm{mmol} / 1$ at the age of 24 hours.

\subsection{Relationship between glucose and insulin concentrations}

Cord and maternal glucose concentrations were closely correlated $(r=0.82 ; n=20 ; p<0.001)$, the former being statistically significantly lower than the latter $(p<0.001)$. There were. statistically significant positive correlations between cord insulin concentration and both maternal glucose concentration $(\mathrm{r}=0.58 ; \mathrm{n}=19 ; \mathrm{p}<0.01)$ and cord glucose concentration $(r=0.82 ; n=20$; $\mathrm{p}<0.001)$. Partial correlation coefficients between maternal plasma glucose $(\mathrm{m})$, cord plasma insulin (i) and cord plasma glucose (g) concentrations were as follows:

$r_{\text {gi.m }}=0.74(p<0.001)$

$r_{g m . i}=0.74(p<0.001)$

$r_{\text {im.g }}=-0.28(p>0.1)$

Where the distribution of the values permitted statistical evaluation, no significant relationship was demonstrated between insulin and glucose concentrations at any other time in the first 24 hours of life.

When the 11 infants who developed hypoglycemia were compared with the 14 remaining infants, there was no significant difference in maternal or cord glucose concentration, or in cord insulin concentration.

\subsection{Effects of infusion of glucose in mother}

There was no relationship between the administration of glucose to the mother during labor and the subsequent development of hypoglycemia in the infants. The highest cord plasma glucose concentration $(16.1 \mathrm{mmol} / \mathrm{l})$ was found in an infant whose mother received an infusion of 10 per cent dextrose during labor; although the cord plasma insulin concentration was $374 \mu \mathrm{U} / \mathrm{ml}$, the baby never became hypoglycemic.

\subsection{Anthropometric assessment}

No relationship was found between the development of hypoglycemia and the weight, skinfold thickness, crown-rump length/thigh skinfold thickness ratio (as suggested by SHENNAN [18]), head circumference/weight ratio and weight/crownheel length ratio of the infant.

\subsection{Post-partum intravenous glucose tolerance tests}

In each of the nine mothers on whom it was performed, the post-partum intravenous glucose tolerance test was normal.

\section{Discussion}

Although it has been recommended $[3,20]$ that high-risk infants to be screened for neonatal hypoglycemia should include HFD infants, the 
degree of risk in such infants is uncertain. In previously published studies the incidence of hypoglycemia in HFD infants has varied widely. LUBCHENCO and BARD [11] classified neonatal hypoglycemia by birth-weight centiles and found an incidence of one case in 48 HFD term infants (2\%). GUTBERLET and CORNBLATH [9] demonstrated hypoglycemia in four "large for gestational age" infants in a total inborn population of 6317 infants; if 5 per cent of these infants were HFD, the hypoglycemia rate in such infants would be about 1 per cent. TOH and Ho [23] in a prospective study demonstrated hypoglycemia in 4 per cent of babies weighing more than $4 \mathrm{~kg}$. In contrast, CARAMELLO [2] found hypoglycemia in 18 of 36 HFD term infants, an incidence of 50 per cent, and BRANDT [1] reported an incidence of five in 13 (38 per cent) HFD infants.

Our results support the suggestion that HFD infants are at risk of developing hypoglycemia, particularly in the early hours of life. GUTBERLET and CORNBLATH [9] would classify the hypoglycemia seen in our patients as "early transitional idiopathic". We found the hypoglycemia easily controlled with oral carbohydrate supplements, and only a small minority were symptomatic.

Although the infants studied were, by definition, unusually heavy for their gestational age, we found no evidence that the more obese babies, as assessed by skinfold thickness and various anthropometric ratios, were more liable to develop hypoglycemia than the thinner babies.

Although the study was based on the previous demonstrations $[6,17,18]$ that HFD infants showed rapid glucose disposal and hyperinsulinism similar to that seen in the infants of diabetic mothers, we found no relationship between high insulin concentration and the development of hypoglycemia; the positive correlation between cord insulin and glucose concentrations suggests appropriate rather than excessive insulin secretion. In the nine mothers on whom it was performed, including three whose infants had had neonatal hypoglycemia, glucose tolerance was normal postpartum. We have therefore no evidence that the metabolic disturbance in the HFD infant is similar to that seen in the infant of the diabetic mother, but the rapid post-partum fall in glucose concentration, the development of hypoglycemia in seven of 25 infants ( 28 per cent) at the age of one hour, and the large maternal vein - umbilical vein glucose concentration gradient, point to rapid glucose disposal in these infants, which may account for the development of obesity during fetal life.

\section{Summary}

Diabetic mothers commonly give birth to unusually heavy babies; these babies may show abnormally rapid glucose disposal, and are at risk of developing neonatal hypoglycemia. The birth of an unusually heavy baby may indicate the presence of otherwise unsuspected maternal diabetes; about one-fifth of infants weighing $4.5 \mathrm{~kg}$ or more show enhanced glucose disposal similar to that seen in infants of diabetic mothers, and are also at risk of developing hypoglycemia. Rather than using an absolute birth weight criterion in identifying unusually heavy infants, we have preferred the use of birth weight/gestational age centile, and have studied 25 infants with birth weights above the 95th centile for gestational age. We excluded infants whose mothers were known to have diabetes, pre-eclamptic toxemia or Rhesus iso-immunization. Maternal venous und umbilical venous blood samples were taken immediately after delivery, and capillary blood was taken from the infants at the age of 1 hour. The infants were fed regularly 4-hourly but the volume of feed taken was not regulated. Capillary blood was taken from the infants pre-feed at 4, 8, 16 and 24 hours of age. Clinical assessment of the infant included various anthro-

pometric measurements: Crown-heel and crown-rump lengths, head circumference and left triceps, subscapular, thigh and abdominal skin-fold thickness.

Eleven of the 25 infants had low plasma glucose concentrations ( $\leqslant 2 \mathrm{mmol} / \mathrm{l})$ in the course of the study; in seven the plasma glucose concentration was $\leqslant 1.5 \mathrm{mmol} / 1$. Seven of the infants were hypoglycemic at the age of 1 hour, four with plasma glucose concentrations $\leqslant 1.5 \mathrm{mmol} / \mathrm{l}$. In only three cases was the hypoglycemia symptomatic.

Statistically significant positive correlations were noted between cord and maternal glucose, cord insulin and maternal glucose, and cord insulin and cord glucose concentrations. No significant relationship was demonstrated between insulin and glucose concentrations at any other age. When the eleven infants who developed hypoglycemia were compared with the other 14 , there was no significant difference in maternal or cord glucose concentrations, or in cord insulin concentration, and maternal glucose infusion during labor was not related to the subsequent development of neonatal hypoglycemia. No relationship could be demonstrated between the develop- 
ment of hypoglycemia and any of the anthropometric measurements. Post-partum intravenous glucose tolerance tests were performed on nine of the mothers; all were normal.

It is suggested that heavy-for-dates infants are at risk of developing hypoglycemia, particularly in the early hours of life. This does not appear to be related to hyper- insulinemia; the positive correlation between cord insulin and glucose concentrations suggests appropriate rather than excessive insulin secretion. Although there was. no evidence of maternal diabetes, these infants appeared to show rapid glucose disposal similar to that seen in infants of diabetic mothers.

Keywords: Heavy-for-date infants, hyperinsulinemia, hypoglycemia, insulin, plasma glucose.

\section{Zusammenfassung}

\section{Blutzuckerkonzentration bei übergewichtigen Kindern}

Oft gebären diabetische Mütter übergewichtige Kinder. Diese Neugeborenen zeigen häufig eine Hypoglykämie. Die Geburt eines besonders schweren Kindes kann einen bis dahin unbekannten Diabetes der Mutter anzeigen. Ungefähr ein Fünftel der Kinder, die $4,5 \mathrm{~kg}$ und mehr wogen, haben einen erhöhten Glukoseverbrauch, ähnlich dem der Neugeborenen diabetischer Mütter, und sind ebenso Hypoglykämie gefährdet.

Anstelle des absoluten Geburtsgewichtes wurde die Geburtsgewicht/Gestationsalter Percentile als Kriterium verwendet. Wir beobachteten $25 \mathrm{Kinder}$, die mit ihrem Geburtsgewicht über dem $95 \%$ Percentil lagen.

Kinder, deren Mütter mit Diabetes, Präeklampsie oder Rhesus-Inkompatibilität aufweisen, haben wir aus der Untersuchung ausgeschlossen.

Direkt nach der Entbindung wurden venöse mütterliche und Nabelschnurvenenblutproben, nach einer Stunde Kapillarblutproben der Neugeborenen entnommen. Die Kinder wurden regelmäßig alle vier Stunden gefüttert. Die aufgenommene Nahrungsmenge wurde nicht bestimmt. Vor den Mahlzeiten wurde alle vier, acht, sechzehn und vierundzwanzig Stunden Kapillarblut entnommen. Die klinische Untersuchung des Neugeborenen umfaßte verschiedene anthropometrische Messungen: Scheitel-Ferse, Scheitel-Steiß, Kopfumfang und die Hautfaltendicke des linken Triceps, subskapular, des Oberschenkels und des Bauches.

Elf der 25 Kinder wiesen im Laufe der Studie niedrige Plasmakonzentrationswerte $(\leqslant 2 \mathrm{mmol} / \mathrm{l})$ auf. Bei sieben betrug die Plasmakonzentration $\leqslant 1,5 \mathrm{mmol} / \mathrm{l}$. Nur in drei Fällen wurde die Hypoglykämie klinisch manifest.

Statistisch signifikant positive Korrelationen ergaben sich zwischen den Konzentrationen: a) der Nabelschnur- und mütterlichen Glukose,

b) des Nabelschnurinsulines und der mütterlichen Glukose,

c) des Nabelschnurinsulines und der Nabelschnurglukose.

Keine signifikanten Beziehungen traten zwischen Insulin und Glukosekonzentrationen aller weiteren Altersstufen auf.

Verglichen mit den anderen vierzehn Kindern, wiesen die elf Kinder mit Hypoglykämie keine signifikanten Unterschiede in Mütterlichen- und Nabelschnurglukosekonzentrationen oder in Nabelschnurinsulinkonzentrationen auf. Die mütterliche Glukoseinfusion unter der Geburt zeigte keinen Einfluß auf die spätere Entwicklung einer neonatalen Hypoglykämie.

Keine Verbindung kann zwischen der Entwicklung einer Hypoglykämie und irgendeiner der erhobenen Körpermessungen postuliert werden.

Bei neun der Mütter wurde post partum ein intravenöser Glukosetoleranztest durchgeführt. Alle waren normal.

Zusammenfassend läßt sich festhalten, daß die für ihr Alter übergewichtigen Kinder (Heavy-for-dates infants = HFD) Hypoglykämie gefährdet erscheinen, besonders während der ersten Lebensstunden.

Dies scheint nicht mit einem besonders hohen Insulinspiegel zusammenzuhängen. Die positive Korrelation zwischen Nabelschnurinsulin und Glukosekonzentrationen legt eher eine adäquate als exzessive Insulinausschüttung nahe. Obwohl bei keiner der Mütter ein Diabetes angenommen werden kann, zeigen diese Neugeborenen doch eine hohe Senkung des Glukosespiegels, ähnlich der Senkung, die man bei Kindern von diabetischen Müttern finden kann.

Schlüsselwörter: Blutzucker, Hyperglykämie, Hyperinsulinämie, Insulin, übergewichtige Kinder.

\section{Résumé}

La concentration de glucose plasmatique chez les enfants hypertrophiques

Les mères diabétiques donnent habituellement naissance à des enfants anormalement gros. Ces enfants pẹvent faire preuve d'une utilisation périphérique de glucose anormalement rapide et risquent de développer une hypoglycémie néonatal. La naissance d'un enfant anormalement gros peut être le signe de l'existence d'un diabète maternel, par ailleurs insoupçonné; environ un cinquième des enfants dont le poids de naissance est supérieur ou égal à $4,5 \mathrm{~kg}$ font preuve d'une utilisation périphérique de glucose augmentée de façon similaire à celle d'enfants nés de mères diabétiques, et risquent aussi de développer une hypoglycémie. Pour définir un enfant anormalement gros, nous avons préféré considérer: poids de naissance/âge gestationnel centile plutôt que le poids de naissance absolu, et avons étudié 25 enfants dont le poids de naissance/âge gestationnel était supérieur de 95-ième centile. Nous avons exclu les enfants dont les mères avaient un diabète connu, une toxémie prééclampsique ou une isoimmunisation de type Rhésus. Des échantillons de sang veineux maternel et de sang veineux ombilical furent prélevés juste après l'accouchement et un échantillon de sang capillaire fût prélevé sur chaque 
enfant une heure après. Les enfants furent nourris régulièrement toutes les 4 heures avec une quantité de nourriture libre. Un échantillon de sang capillaire fut prélevé sur chaque enfant avant leur repas à $4,8,16$ et 24 heures de vie. Des mesures anthropométriques variées furent comprises dans l'évaluation clinique de l'enfant: longueur totale (sommet de crâne-talon) longueur corporelle (sommet de crâne-fesses) perimètre crânien, épaisseur de pli cutané gauche tricipital, subscapulaire, abdominal et fémoral.

$\mathrm{Au}$ cours de cette étude, 11 des 25 enfants ont eu, à un moment quelconque, un taux de glucose plasmatique bas $(\leqslant 2 \mathrm{mmol} / \mathrm{l})$. Dans $7 \mathrm{cas}$, le taux de glucose plasmatique était $\leqslant 1,5 \mathrm{mmol} / 1$. Sept enfants furent hypoglycémiques une heure après la naissance, 4 d'entre/d'entre eux avec un taux de glucose plasmatique $\leqslant 1,5 \mathrm{mmol} / 1$. Dans 3 cas seulement l'hypogly cémie était «symptomatique».

Des corrélations statistiquement significatives furent notées entre le taux de glucose maternel et ombilical, le taux de glucose maternel et d'insuline ombilical, le taux d'insuline ombilical et de glucose ombilical. Aucune corrélation significative n'a pu être démontrée entre le taux d'insuline et de glucose à aucun autre moment. Nous n'avons retrouvé aucune différence significative entre les 11 enfants qui ont dévelappé une hypoglycémie et les 14 autres, au niveau des taux de glucose maternels ou ombilicaux ni au niveau des taux d'insuline ombilicaux. Il n'a pas été noté de corrélation entre une perfusion de glucose pendant le travail et le développement consécutif d'une hypoglycémie néonatale. Aucune corrélation non plus entre le développement d'une hypoglycémie et les mesures anthropométriques n'a pu être demontrée. Neuf des mères ont eu, en période de post partum, un test intraveineux de tolérance de glucose. Ils ont tous été normaux.

Ces résultats suggèrent que les enfants gros par rapport à l'âge gestationnel risquent de développer une hypoglycemie, particulièrement au cours des premières heures de la vie. Ceci n'apparait pas lié à une hyperinsulinémie; les corrélations positives entre les taux de glucose et d'insuline ombilicaux suggèrent une sécrétion d'insuline appropriée et non pas excessive. Bien qu'il n'y ai aucune évidence de l'existence d'un diabète maternel, ces enfants sembient faire preuve d'une utilisation périphérique de glucose rapide, semblable à celle retrouvée chez des enfants nés de mères diabétiques.

Mots-clés: Enfants hypertrophiques, glucose plasmatique, hyjperglycémie, hỷperinsulinémie, insulin.

Bibliography

[1] BRANDT, I.: Frequency and importance of hypoglycemia in the neonate. J. Perinat. Med. 10, Suppl. 2 (1982) 39

[2] Caramello, M. T. G., L. Fogli, G. GUAla: Programma di screening nel neonato. Minerva Pediatric 30 (1978) 989

[3] CORNBLATH, M.: Fetal and neonatal hypoglycemia. J. Perinat. Med. 10, Suppl. 2 (1982) 33

[4] CORNBLATH, M., R. SCHWARTZ: Disorders of carbohydrate metabolism in infancy. Saunders, Philadelphia 1976

[5] DUNCAN, J. M.: On puerperal diabetes. Trans. Obstet. Soc. Lond. 24 (1882) 256

[6] FALORNI, A., F. MASSI-BENEDETTI, F. FRACASSINI, E. GIANNONE, R. BRUNORI: Studio sulla tolleranza glucidica e sull 'increzione di insulina nei neonati macrosomi e nelle loro madri. Minerva Pediatrica 26 (1974) 728

[7] FARR, V.: Skinfold thickness as an indication of maturity of the newborn. Arch. Dis. Childh. 41 (1966) 301

[8] FARR, V., D. F. KERRIDGE, R. G. MITCHELL: The value of some external characteristics in the assessment of gestational age at birth. Develop. Med. Child Neurol. 8 (1966) 657

[9] GUTBERLET, R. L., M. CORNBLATH: Neonatal hypoglycemia revisited, 1975. Pediatrics 58 (1976) 10

[10] LILIEN, L. D., L. A. GRAJWER, R. S. PILDES: Treatment of neonatal hypoglycemia with continuous intravenous glucose infusion. J. Pediat. 91 (1977) 779
[11] LUBCHENCO, L. O., H. BARD: Incidence of hypoglycemia in newborn infants classified by birth weight and gestational age. Pediatrics 47 (1971) 831

[12] LUNELL, N.-O.: Intravenous glucose tolerance in women with previously complicated pregnancies. Acta Obstet. Gynecol. Scand. 45, Suppl. 4 (1966) 1

[13] MICKAL, A., W. P. BEGNEAUD, W. H. WEESE: Glucose tolerance and excessively large infants. Amer. J. Obstet. Gynec. 94 (1966) 62

[14] MILLER, H. C.: The effect of the prediabetic state on the survival of the fetus and the birth weight of the newborn infant. New Engl. J. Med. 233 (1945) 376

[15] MORRISON, B., C. J. SCOTLAND, A. FLECK: The determination of plasma glucose in a diabetic clinic. Clin. Chim. Acta 39 (1972) 301

[16] PAGLiara, A. S., I. E. KARL, M. HAYMOND, D. M. KIPNIS: Medical progress. Hypoglycemia in infancy and childhood. J. Pediat. 82 (1973) 365

[17] PERSSON, B., G. STERKY, B. STRANDVIK: Intravenous glucose tolerance in overweight newborn infants and their mothers. Pediatrics 45 (1970) 589

[18] SHENNAN, A. T., G. RUSSELL, H. W. SUTHERLAND, J. M. STOWERS: Glucose tolerance in the heavy-for-date neonate - a pilot study. J. Perinat. Med. 8 (1980) 112

[19] SKIPPER, E.: Diabetes mellitus and pregnancy a clinical and analytical study (with special observations upon thirty-three cases). Quarterly Journal of Medicine (New Series) 2 (1933) 353

[20] STEVENS, D., R. L. SCHREINER: Neonatal hypoglycemia. J. Indiana State Med. Assoc. 71 (1978) 485 
[21] SUTHERLAND, H. W., J. M. STOWERS: The detection of chemical diabetes during pregnancy using the intravenous glucose tolerance test. In: SUTHERLAND, H. W., J. M. STOWERS (eds.): Carbohydrate metabolism in pregnancy and the newborn. Churchill Livingstone, Edinburgh 1975

[22] THOMSON, A. M., W. Z. BILLEWICZ, F.E. HYTTEN: The assessment of foetal growth. J. Obstet. Gynaec. Brit. Cwlth. 75 (1968) 903

[23] TOH, C. C., N. K. HO: A 30 months prospective clinical study on hypoglycaemia in high risk neonates. J. Singapore Paediat. Soc. 21 (1979) 254

[24] VEREL, D., A. B. KESTERVEN: Forceps for the measurement of skin-fold thickness. Lancet 2 (1960) 962
[25] WORLD HEALTH ORGANISATION: Diabetes mellitus. Technical Report Series, No. 310 WHO Geneva 1965

Received December 7, 1982. Accepted February 9, 1983.

Dr. George Russell

Department of Child Health

University Medical Buildings

Foresterhill

Aberdeen AB9 2ZD

Scotland

UK 